\title{
INNOVATIVE MULTIFUNCTIONALITY IN BUILDING COMPETITIVE POSITION OF RURAL PERIPHERAL AREAS
}

\author{
Janusz ZROBEK \\ University of Lodz, Faculty of Management, Department of Marketing, Łódź; janusz.zrobek@uni.lodz.pl, \\ ORCID: 0000-0002-7585-0582
}

\begin{abstract}
Purpose: The aim of the study is to present opportunities for the development of innovative multifunctionality as a driving force of economic growth and improvement of living conditions in rural areas.

Design/methodology/approach: The considerations were based on a critical analysis of the literature on the subject and materials obtained from online sources.

Findings: The main factor of increasing the potential of rural areas are innovative activities enriching the rural economy, conducive to its compatibility with modern economic and social structures. They contribute significantly to the revitalization of the socio-economic fabric of the countryside, by creating new types of economic activity, developing multifunctionality conducive to creating real foundations for achieving sustainable economic growth. However, the future of the village cannot be built solely on its internal resources. Rural development is largely determined by external forces linked to markets and technology. The countryside requires significant innovative cooperation with external areas.

Originality/value: In-depth analysis of the creation and adaptation of multifunctional innovations taking into account the appropriate combination of factors related to the local environment with factors related to general economic changes that brings global interdependence, as well as support for extensive business connections.
\end{abstract}

Keywords: multifunctionality, innovation, competitiveness, peripheral areas rural.

Category of the paper: Research paper.

\section{Introduction}

The changes taking place in the economies in recent decades have led to the need to change the existing rural economic configurations, undermining the possibilities of further development of rural communities based on traditional patterns of production activities (Heffner, 2011). Contemporary production relations influence the need to modify relations in existing economic structures. The growing tendency to market and increase productivity requires, especially in peripheral rural areas, the introduction of noticeable changes in the 
production structures of the village. Maintaining and, above all, improving the competitive position of rural peripheral areas is associated with the need to modernize business operations. In particular, the need to increase the diversification of doing business in rural areas is revealed (Kłodziński, 2014).

The key feature of these changes is multifunctionality expressed in the simultaneous and interrelated performance of various economic functions (Ploeg van der, and Roep, 2003). Sustainability of effects to improve living conditions in rural areas requires the introduction of an innovative multi-functional economy, dissemination of employment outside agriculture and investment in human capital. Premises to obtain the resulting benefits are especially provided by adopting an orientation focused on broadly understood innovation (Zrobek, 2017). Poorly developed rural areas, thanks to the use of innovation in developing their own potential, can improve the economic structure and competitive position, especially when the efforts made are combined with transformations in the demand structure. Innovative multifunctionality is a certain mechanism of integrated development and a tool that allows giving value to the built territorial potential (Marsden, and Sonnino, 2008). It forms the basis for its more effective development and the possibilities of managing its resources.

Hence, the purpose of the study is to analyze the role and importance of innovative solutions based on the introduction of multifunctionality to improve economic conditions in the development processes of peripheral rural areas.

\section{Village development opportunities}

As a result of the polarization of the economic space, and the increasing differences between the developed core and weakened peripheral areas, a number of economic and social problems are growing in the latter, manifested by progressive depopulation processes, with already low population density, aging of the society, weak economic activity, budget deficit, low investment potential, social diversity, low urbanization, limited accessibility and outdated economic structure or infrastructure shortages. Adapting to new market conditions is particularly difficult in areas that do not have diverse functions, and agriculture is the dominant branch of their economy. This leads to a decrease in the quality of employee resources, migration, reduction of economic activity and, as a consequence, the deepening marginalization of peripheral areas. The generally poor economic situation and the lack of local demand do not encourage new investment in such areas.

This situation, however, is often largely the result of not so much the lack of any economic perspectives, but the lack of skills to properly assess and especially the ability to use the potential of the peripheral areas and to introduce new opportunities to develop this potential. 
Peripheral regions also have their own development capacities. The problem boils down to their identification and implementation of pro-development activities.

Rural regions, whose economic opportunities for many years were underestimated and treated as quite limited, are now more and more often perceived as areas with potential for development. Rural territorial areas are not necessarily condemned to failure and economic decline because they present a number of potential opportunities and have different possibilities. They are not doomed only to social and economic marginalization. They can also be places of growth, opportunity and inspiration. They have a crucial role to play in important economic challenges. There are, among others best prepared to maintain the environment, ensure food security or create new energy sources.

Although in the conditions of emphasized distance to centers of innovative growth, shortage of qualified labor force, reduced educational opportunities or lack of access to capital, it is difficult to expect a flourishing creative economy, but the physical nature of resources located in rural areas remains an advantage. This is typical for peripheral regions whose development is largely based on their resources. Their development abilities are seen mainly in the context of perceiving the specific values they can offer. Based mainly on the uniqueness of their territorial capital expressed in natural, cultural and symbolic conditions and quality of life. Their economic base, despite the visible decline in the importance of agriculture and traditional sectors, gives growth opportunities for other activities, such as services and recreation, in line with the postulate of the "new rural paradigm" (OECD, 2006).

However, one should also strive to enrich the economic structure with modern activity based on digitization, automation and robotization creating not only significant changes in existing industries but also the basis for creating new types of activities. Poor development abilities resulting from low innovativeness, low competences or insufficient demand for the offered products should find a solution not only in the attempt to modernize and develop activities considered typical for rural space, but primarily in the implementation of innovative projects introducing high economic potential, driving local development. Peripheral areas cannot be considered an area cut off from innovation. They are able to develop modern forms of competitiveness that are not the exclusive domain of large growth centers.

Peripheral rural areas are currently also experiencing certain institutional, economic and social changes enabling the creation of conditions for creating or receiving new knowledge. It is therefore necessary to consider how the peripheral location can use the benefits of the creative economy and knowledge and contribute to the creation of a modern economy.

Given the diversity of rural areas and their specificity, it seems that creative economy in peripheral conditions should, as far as possible, take its own forms and separate, unique designs. This approach in rural areas seems particularly important. You should also be aware that the possibilities of individual peripheral regions are heterogeneous, and these differences can be significant. This requires an approach that allows the implementation of development strategies based on an assessment of their potential with a clear definition of the priorities for this 
development. However, this is not an easy challenge for neglected rural areas, usually characterized by a small number of inhabitants, relatively low income, low level of education and a considerable distance from regional economic centers.

For rural peripheral areas, most often struggling with a fairly one-sided economy dependent on traditional fields of activity, it becomes necessary to move to the development phase based on building new resources (Halamska, 2018; Maurel, 2018). Alternatives are needed to widespread existing fields of activity and conventional solutions in traditional rural sectors that ensure less and less return on investment, expressed in the transition to more competitive activities and more adapted to the rapidly changing economic situation. There is a growing need to pursue investment and performance activities. However, it depends to a large extent on the diffusion capacity, absorption capacity and adaptability of technologies developed externally. The region's ability to react to new circumstances is important: adopting solutions that are already successfully used in other regions (adapting them to their own specific structures and conditions) or developing entirely new solutions. These types of changes will favor the increase of socio-economic attractiveness of rural areas.

Efforts should be focused on activities in these areas in which you can develop a competitive advantage. Undoubtedly, proper links are needed here for the economies of local units with the directions of economic development of external units so that the local economic fabric can benefit from the development of entire regions. This requires the ability to absorb, adapt and transfer modern solutions and knowledge from the outside world. So that there is practical connection and involvement of the village in global development processes. This will create a greater variety of goods and services. Consequently, new jobs will be created related to product development, marketing, sales, distribution, etc.

The village must use and develop its abilities to enable innovation. Otherwise, it will lead to a situation in which various types of activities do not complement each other, and therefore the potential assets of peripheral units will not be fully utilized to improve their competitiveness. An approach based on current conditions is advisable, supported by a thorough specialist effort for innovations enabling the most comprehensive development possible.

\section{The importance of using innovation for modern development of rural peripheral areas}

In the face of challenges facing rural areas, where there are strong economic and environmental changes and sociological changes associated with the emergence of new patterns of existence and increased mobility opportunities for their inhabitants, as well as difficulties related to rural areas, innovation is becoming one of the most important elements of the development of peripheral areas rural areas. 
Nowadays, innovations are a key factor of economic growth and decide about competitive abilities and socio-economic development of a rural community. Innovations are perceived to a large extent as a territorial phenomenon and often considered as a result of specific local conditions that cannot be quickly and advantageously copied or even transferred elsewhere. Territorial targeting is necessary as regions are highly heterogeneous. Hence the importance and role of the local environment as the background for innovative processes (Kutkowska, and Hasiński, 2018). Territorial embedding of the innovation process is strongly emphasized. It highlights the role of opportunities arising from a given spatial environment for conducting innovative activities (Zajda, 2013).

The use of diversity and specific competitive advantages resulting from innovation should be one of the basic objectives in the socio-economic development of rural space. This finds a special reference to activities strongly territorially located and organically related to the properties of the area in which it is conducted (Bański, 2017).

Not every innovation can be adapted in every region, because you have to take into account the specific possibilities, needs and problems of a given local community. It is necessary to take into account the so-called the specifics of the place (Isaksen, and Nilsson 2012; Morgan, 2017). When introducing innovations, the specific features of rural areas, such as territorial capital, natural and cultural amenities, rural lifestyle, and quality of life should be seen. Particularly important is "territorial capital", which includes factors such as geographical location, size, equipment, climate, traditions, and natural resources (OECD, 2001).

Innovations in rural territory are associated with the conditions of sustainable development, recomposition and division of space, communication of entities ensuring competitiveness in these areas and new economic development. They cover all initiatives of an innovative or unusual nature. Their introduction into the existing economic system should take place in an economically justified and socially acceptable manner, taking into account local and supralocal conditions. Innovative activity is effective especially when it refers to existing solutions. This is a kind of adaptive function, consisting in stabilizing reality. In most successful cases, innovations are not based not so much on new inventions, but on the use of existing ones (Rajalahti, Janssen, and Pehu, 2008). They are usually a response to market demand or the need to solve a specific problem. They are related to practical usability and ability to apply in a given reality. They allow to strengthen the existing and retaining the importance of structure in some important aspects, by modifying them, using factors favoring the use of local production and adding new ingredients that enrich the whole (Casini, Contini, and Romano, 2012).

Innovations can be read as a new development lever for a given territory. It is the starting point for lasting competitive advantage of individual rural areas and the possibility of success, it fundamentally affects their economic growth. Innovations affecting growth in productivity and turnover create far-reaching opportunities for rural enterprises to create competitive advantage and their further development. Among the most important development factors, they have highly noticeable consequences for business opportunities. Performance increase 
based on innovative technologies is systematically transforming the areas of production and services. It manifests itself not only in improved technology but also in increased mobility of people, capital, information and various factors that form the basis for the production of goods and services.

The opportunities created by the development of innovation are dynamic, new solutions are emerging that can change the competitive situation. Limiting the possibilities in many traditional types of activity can be replaced by innovative production and distribution activities as well as broadly understood service industries enabling the release of various types of professional activity. There are also opportunities to increase innovation and create new values based on emerging interaction opportunities, investment in new activities and other market opportunities. The more so because specific local and regional conditions can contribute to stimulating innovative activity.

Rural peripheral areas are generally not, or only to a very small extent, locations of new solutions and modern technologies. And that's exactly what needs to be changed. This is even more important because so far they are characterized by less innovation compared to developed regions, and the intensity of these innovations is low, they have a much less developed knowledge infrastructure, they also experience various organizational weaknesses. At the same time, it is believed that the uneven spatial distribution of innovative activities means that territorial units, especially those with a poorly developed economy are not able to use and especially develop innovative potential, and often they can't even fully absorb it (Halamska, 2018)

However, rural areas should strive to exploit the opportunities associated with innovation in new technologies, products or processes as much as possible. They can be economically strong in a local context, and growth depends on an innovative combination of knowledge and ideas. It is the innovation processes that take place in spatial units, their innovative ability to introduce original solutions, give an impulse to the development of the areas in which they are located. They release human creativity and increase competitive ability. The real value that is created is no longer in the material processing of raw materials and materials, but in creating new, specific service concepts and an integrated offer (Zrobek, 2015).

Especially since innovation is not limited to high-tech solutions, in many cases they can be based on products with lower technology, services and hybridization-based concepts (i.e. combining elements with different solutions and technologies). They can be acquired through adaptation and transfer to new territories or new economic entities.

Rural areas have a certain degree of independence, independent creation of innovations, especially in the field of entrepreneurship or the use of own resources. Innovations based on their own local assets and endogenous abilities of rural peripheral areas are manifested as the basic driving force of economic development, which provides the surest way to reconcile global economic reality and local modernity. They allow the creation of an innovative business climate, functional closeness increases the possibilities of local enterprises for interaction, 
cooperation and deepening of personal contacts, which in turn enables a more comprehensive diffusion of innovation. Due to the endogenous nature of such innovation, it may be most useful in overcoming the marginalization of peripheral areas and its effects.

In addition, the periphery can "learn" and make extensive use of external knowledge transfers. They should build a development strategy taking into account connections with national (and even global) markets and innovation centers. They need to import modern solutions and technologies in order to increase their competitive abilities. Especially in a situation where the historically shaped local technology base is narrow and offers few new growth opportunities, local enterprises can find significant benefits in engaging in building new complementarities and synergies with various types of technologies. However, due to developmental delays in peripheral rural areas, supra-regional cooperation and the benefits based on technological links may be lower than in advanced regions.

The competitiveness of each spatial unit increases with the innovation of the offer and the following (as a consequence of the multiplier effect) factors such as: increasing qualifications, competences and knowledge of residents, attracting new resources and external investments, enhancing technological and organizational innovation, and progressive development of pro-innovative infrastructure (mainly business service institutions). The innovative offer has a competitive impact, mainly as an alternative proposal and as a factor of competition for available funds of the potential recipient.

The introduction of innovations should strengthen the strategic diversification of activities carried out in rural areas. It is necessary to add new elements to their economy, society as well as culture and through new opportunities for rural development ensure the increase of its competitive position in the region. This is usually done by transforming traditional economic structures paving the way for new opportunities. It is assumed that in many particularly traditional economies these innovations are non-technological (they relate in particular to processes, organization, marketing), and as such better respond to the needs of micro- and small business entities, which in the peripheral areas constitute the dominant part of the economic structure.

\section{Innovative aspects of the development of multifunctionality in the countryside}

Multifunctional development of rural areas is associated with the diversity of the rural economy, i.e. abandoning the treatment of these areas as strictly monofunctional zones (in the case of such areas with a definite advantage of agricultural function), where the production of plant and animal raw and related activities constitute the dominant or the only function (Heffner, 2011; Wilkin, 2011; Kłodziński, 2012). Multifunctionality of rural areas is 
a territorial concept referring to the multitude of functions that can be developed in rural areas. It is based on incorporating into the rural space additional non-agricultural functions related but also not related to the rural environment, allowing for a deeper use of dispersed territorial capital. Local economic diversity is one of the main aspects of the sustainable development of rural communities. Diversification generates local employment opportunities and creates networks of strong economic interdependence (Heffner, 2011).

The development of local markets, local production, local processing of acquired resources and closer cooperation between local economic entities are necessary to improve the economic competitiveness of villages, especially areas that have been marginalized so far. As a result, economically strong local communities may be created, increasingly connected with larger structures and increasingly able to integrate with general economic processes. Their role and significance are growing and are becoming an indispensable link in the modern economy, whose existence and further dynamic development is indispensable for her.

Multifunctionality is a complex and diverse phenomenon. They are characterized by multidimensionality as the strict separation of various functions related to production, services, recreation or protection of natural values is difficult or even impossible. From a practical point of view, moreover, usually quite unreasonable. This manifests itself in a number of different, most often connected practices. At the same time, in the case of less developed areas, diversification should not be too narrow and even broad actions beyond the existing scope are recommended (Ploeg van der, and Roep, 2003). This applies, for example, to activities related to the rural environment, such as landscape management, protection of new natural values, agrotourism, organic farming, production of high-quality products specific for a given territory, or conducting care activities as well as various medical services.

Involvement in this type of undertaking leads to functional coherence and new relationships are established not only with other entities located in the peripheral areas but very importantly with those located in cities and also in more developed rural areas.

The multifunctionality of rural areas is strongly associated with the practice of modernizing rural areas. Bringing practical benefits through its implementation requires therefore giving it an innovative character. Only the introduction of modern, knowledge-based, diverse solutions that use functional diversification will provide real development opportunities for peripheral rural areas. This will give rise to new product and service markets and allow for rapid dissemination of technology among traditional and new industries.

Its most important and expressive manifestations affecting rural development are (Ploeg van der, and Roep, 2003):

- Establish and consolidate new links between agriculture and the general public. Transforming agriculture allows us to meet changing consumer needs.

- Creating and further developing new opportunities to increase the income of rural residents. Modern modernization allows raising the socio-economic level of both the rural economy and the farm. 
- Recreation, transformation and development of rural resources: new resources are mobilized and combined with existing, in accordance with new development trends, they create new, innovative, ecologically sustainable, strong economic constellations. New resource combinations allow the creation of a network of new connections connecting peripheral areas with external markets.

In this context, structural diversification based on the development of agricultural, industrial and logistics technology and infrastructure enabling the inclusion of given areas in supra-local value chains is most desirable. It allows creating the basis for continuous diffusion of innovation and adoption of innovative economic diversification, increasing investment attractiveness, and ensuring innovation and development not only of information and communication technologies. On the one hand, new functions must be developed, new competences generated, and at the same time integration and market coherence be created.

Multifunctionality in rural areas in the form of functional diversification takes two forms. It manifests itself in activities related to agriculture and in activities aimed at non-agricultural applications of available resources. It is particularly valuable to stimulate an innovative approach to diversified rural development at the local level through small-scale activities and valorisation of local physical and human resources.

New types of activity require consideration of both the specific features of rural areas and types of economic activities typical of such areas as well as the incorporation of modern enterprises into the rural economy, including their links with external (mainly urban) economic spheres, as an important facor of development potential. One should deepen these ties, strive for stronger integration, and increase of supra-local connections. Particularly important for rural development are the types of activities for which demand comes from urban residents.

Multifunctional agricultural activity based on various activities, is associated with entrepreneurial, new land use, among others enabling reduction of intensity as well as restructuring and diversifying agricultural production, for example in the form of organic production, maintaining biodiversity of crops, increasing biological production and the adoption of specializations that improve the structure of agriculture and the quality of products.Its impact on the preservation and improvement of the rural environment, and its contribution to the vitality of rural areas is important. Agriculture responds to new needs, leading to profitable multi-functionality, allowing it to contribute to the socio-economic viability of many peripheral rural areas.

Among the functions related to the rural economy, the development of tourism is indicated, in particular agritourism, i.e. tourist activity taking place on a farm, the pursuit of a more beneficial, based on technical progress, use of renewable raw materials of organic origin for energy production, innovative use of the uniqueness of resources (natural and economic), as evidenced by their origin, culture of production, coexistence with nature, rarity of raw materials, as well as ecological and health properties (Zajda, 2013), introducing innovative directions of action directed at the development and maintenance of biodiversity, or especially 
the now popular, broadly understood sphere of culture including art, cultural heritage, artistic activity, artistic and applied crafts, design, integration of art with everyday life.

Diversification towards non-agricultural uses of available resources, most often manifests itself in the form of such as catering for tourists, blacksmithing, carpentry, spinning, practically diversification in any activity other than agriculture-only, and in particular the use of resources other than land, water, forests, buildings, available skills and local characteristics, boosting entrepreneurship in rural areas. Entrepreneurial combination of various resources allows to stimulate tourism, sport and recreation, vocational and technical training, retail and wholesale trade, industrial activities (engineering, crafts), servicing (consulting), creating added value (processing - meat, milk, wood products etc.) and the opportunity to work outside the farm.

The entrepreneurship of the rural population will allow the emergence of new and diverse innovative types of activities, including, for example (Casini, Contini, and Romano, 2012): recycling services, manufacture of pressed alfalfa products, sale of cut flowers, production of organic yogurt, restoration of native plants, distribution of wholesale pizza products, maintenance and repair of microelectronic equipment, production of neon lights and exhibits for retail trade and services, cultivation and sale of shiitake mushrooms and oyster mushrooms or the production of a new type of energy-saving garden lighting. Therefore, economic activity in rural areas requires changes consisting in its deepening and broadening, enabling the achievement of a new, structurally differentiated, level of development in the rural environment, based on the development of many various new or modernized activities.

Deepening includes activities that enable the reorganization of the production system to develop products and production processes. As a result, quality improvement is expected, development of processing processes that give the product added value, and closer relations with market partners are established.

Enlargement is primarily the introduction of activities that go beyond traditional functions. These mainly include activities related to the specificity of the rural environment, such as agritourism, environmental services, activities for cultural heritage, and production of raw materials for industry. Although not all are closely related to agricultural activity, they are associated with the development of multifunctional aspects of the rural environment. To this should be added the introduction of activities largely independent of the rural environment, primarily based on modern technological domains.

As a result, the economic structure of rural areas will expand, their impact will spread, new markets will be acquired, ties between rural enterprises and external business entities as well as consumers from other regions, mainly cities, will increase.

Considering the above, certain orientations for the introduction of innovative multifunctionality and its impact on the diversification of the existing economic structure in peripheral rural areas can be distinguished: 
- introducing innovative improvements in activities related to production and assets agricultural, focusing on multifunctionality of agriculture, diversification of agricultural holdings, development of agri-environmental measures and diversification of basic agricultural activity,

- developing on a larger scale innovative, non-agricultural activities related to the rural environment, allowing for supplementing, expanding, creating configurations of activities related to the rural economy (e.g. with the decline in the importance of agriculture, an increase in the share of other activities taking into account the specificity of rural activities, especially services - related to tourism and recreation, health, education, transport),

- diversification of non-agricultural activities through the introduction and dissemination in the peripheral areas of diverse, completely new types of activity, mainly new technologies, especially ICT and biotechnology, modern technological domains largely independent of the rural environment,

- pursuit of rural development by developing a multi-functional, integrated territorial approach, supporting the diversification of activities (especially related to local initiatives), leading to thoroughly modernized economic activity based on respect for and protection of the specificity of rural areas.

Developing modern multifunctionality in rural peripheral areas is all the more important in a situation where mature market economies are increasingly changing and evolving towards creating a diverse mix of production and service activities, especially as part of non-agricultural activities (Whitener, and McGranhan, 2003). The traditional sector based on the agricultural economy can no longer be the main source of development and is less and less a source of competitiveness (Zrobek, 2017). This role is taken over by new business activities developed and transferred to rural areas, conditioning the creation of modern, prospective jobs. It will allow the development of networks of connections, establishment and intensification of multilaterally beneficial cooperation leading not only to a gradual increase in the achieved revenues, but also to the economic importance of marginalized rural areas. It is necessary to implement new solutions aimed at their more competitive and effective multi-functional activation.

\section{Conclusion}

Peripheral rural areas are a specific area that deserves development. It is a different, clearly distinguishable type of area, possessing qualities that should be maintained. Its basic, specific value is still natural resources and agricultural production but they need support with new technology and especially new types of entrepreneurship. 
Challenging existing threats for the development of these areas requires a comprehensive understanding of their full potential and existing barriers (bottlenecks), as well as adopting a new set of innovative conduct rules that will allow for gradual strengthening of collective educational mobilization and creation of local capital. Innovative activity resulting from the opportunities created by adopting a multifunctional rural development model can serve as a drive for local economic development raising the level of its competitiveness. Innovations are particularly important for the diversification of less economically advanced areas. In such regions, multifunctionality based on innovations promotes greater adaptation of opportunities and provides new development opportunities.

Multifunctional areas based on significant innovative activity are characterized by: large employment opportunities, diversified production structures, relatively large employment shares in non-agricultural professions, a relatively large number of small plants, a high level of technical equipment and convenient communication connections. Local resources, local relations between the city and the village, local initiatives and local entrepreneurship are key to innovative multifunctional rural development.

However, the future of the village cannot be built solely on its internal resources. The development of agriculture and rural areas is relatively determined by external forces related to markets and technology. A competitive village needs a broad interaction based on an innovative approach with external areas. Therefore, natural facilities and conditions are necessary to attract innovative and entrepreneurial resources from urban areas, which can be helpful in stimulating multifunctional innovation in rural areas.

The rural economy is transforming from simple agricultural production to dominated by more advanced technology and the development of services oriented to external markets. Diversification brings real potential that contributes to increasing the competitiveness of rural areas. Its innovative nature allows for higher economic growth, new business models, better services and a higher standard of living. Effective implementation of innovative processes based on multifunctionality can be the main driving force of change in the economies of peripheral rural areas.

\section{References}

1. Bański, J. (2017). Rozwój obszarów wiejskich. Warszawa: PWE.

2. Casini, L., Contini, C., and Romano, C., (2012). Paths to developing multifunctional agriculture: insights for rural development Policie. International Journal of Agricultural Resources Governance and Ecology, 9, 185-203.

3. Halamska, M. (2018). Wspierać czy zalesiać? Dylematy rozwoju wiejskich obszarów problemowych. Wieś i Rolnictwo, 2, 69-91. 
4. Heffner, K. (2011). Wielofunkcyjność obszarów wiejskich w Polsce - rzeczywistość czy mit? Ewolucja zagospodarowania przestrzeni wiejskiej. Studia KPZK, 133, 8-26.

5. Isaksen, A., and Nilsson, M. (2012). Combined Innovation Policy: Linking Scientific and Practical Knowledge in Innovation Systems. International European Forum, February 13-17, Innsbruck-Igl: Austria. https://ideas.repec.org/p/ags/iefi12/144864.html, 4.08.2019.

6. Kłodziński, M. (2012). Bariery wielofunkcyjnego rozwoju obszarów wiejskich. Wieś i Rolnictwo, 2, 40-56.

7. Kłodziński, M. (2014). Przedsiębiorczość pozarolnicza na wsi w procesie wielofunkcyjnego rozwoju obszarów wiejskich. Wieś i Rolnictwo, 1, 97-112.

8. Kutkowska, B., and Hasiński, W. (2018). Wielofunkcyjność - Nowe spojrzenie na rozwój obszarów wiejskich. Wieś i Rolnictwo, 2, 113-131.

9. Marsden, T., and Sonnino, R. (2008). Rural development and the regional state: Denying multifunctional agriculture in the UK. Journal of Rural Studies, 24(4), 422-431.

10. Maurel, M.C. (2018). Gdy wieś zmienia ustrój. Ścieżki rozwojowe wsi w Europie Środkowej. Wieś i Rolnictwo, 2, 49-65.

11. Morgan, K. (2017). Nurturing novelty: Regional innovation policy In the age of smart specialisation. Environmentand Planning C: Politics and Space, 35(4), 569-583.

12. OECD (2001). Multifunctionality: Towards an Analytical Framework. Paris, France.

13. OECD (2006). Investment Priorities for Rural Development. Edinburgh, Scotland. Retrieved from http://www.oecd.org/regional/regional-policy/Investment-Priorities-forRural-Development.pdf, 17.02.2019.

14. Ploeg, van der J.D., and Roep, D. (2003). Multifunctionality and rural development: the actual situation in Europe. In: G. van Huylenbroeck, and G. Durand, Multifunctional Agriculture; A new paradigm for European Agriculture and Rural Development (pp. 37-53). Hampshire, England: Ashgate.

15. Rajalahti, R., Janssen, W., and Pehu, E. (2008). Agricultural Innovation. Systems: From Diagnostics toward. Operational Practices. The International Bank for Reconstruction and Development/The World Bank, http://siteresources.worldbank.org, 27.04.2018.

16. Whitener, L., and McGranhan, D. (2003). Rural America: Opportunities and Challenges, Amber Waves. Economic Research Service, 1, 15-21.

17. Wilkin, J. (2011). Wielofunkcyjność wsi i rolnictwa a rozwój zrównoważony. Wieś i Rolnictwo, 4, 27-39.

18. Zajda, K. (2013). Innowacja w wiejskiej przedsiębiorczości. Studia Regionalne i Lokalne, $1,90-104$.

19. Zrobek, J. (2015). Innowacyjne przejawy konkurencyjności słabo rozwiniętych wiejskich jednostek terytorialnych. Marketing i Rynek, 10, 406-415.

20. Zrobek, J. (2017). Innowacje w rozwoju przedsiębiorczości słabo rozwiniętych obszarów wiejskich. Handel Wewnętrzny, 4, 343-356. 